\title{
Application of Electrical Resistivity Imaging in Investigating Groundwater Pollution in Sapele Area, Nigeria
}

\author{
Okezie Uchegbulam, Elijah A. Ayolabi \\ Department of Geosciences, University of Lagos, Lagos, Nigeria \\ Email: okezie uchegbulam@yahoo.com, eojelabi@yahoo.com
}

Received 13 August 2014; revised 8 September 2014; accepted 2 October 2014

Copyright (C) 2014 by authors and Scientific Research Publishing Inc.

This work is licensed under the Creative Commons Attribution International License (CC BY). http://creativecommons.org/licenses/by/4.0/

\section{c) (i) Open Access}

\begin{abstract}
Sixty-four multi-electrode Lund imaging system coupled with ABEM SAS 4000 Terrameter was used for the electrical imaging of the study area. Wenner and Gradient arrays with $\mathbf{2} \mathbf{m}$ minimum electrode spacing were employed which revealed resistivity changes in the vertical and horizontal directions along the survey lines. Earth imager software was employed for the processing and the iteration of the 2-D resistivity data. The subsurface is characterized with soil material with resistivity ranging from $42-15,000 \mathrm{Ohm}-\mathrm{m}$, reflective of varying degree of conductivity associated with changing lithology and fluid type. Correlation with borehole data shows that the first $10 \mathrm{~m}$ is composed of laterite. While sand materials occupy 10 to about $60 \mathrm{~m}$ beneath the surface, with anomalously high resistivity $\leq 15,000 \mathrm{Ohm}-\mathrm{m}$ in most parts. These high resistivity formations can be attributed to the presence of hydrocarbon within the subsurface, which is an indication that shallow aquifer in the study area has been polluted. The water level in the study area is close to the surface, between $4-5 \mathrm{~m}$. As a result of the high resistivity formations in most parts, deep wells of about $45 \mathrm{~m}$ are recommended after geophysical investigations.
\end{abstract}

\section{Keywords}

Electrical Resistivity, Imaging, Pollution, Traverse Lines

\section{Introduction}

A groundwater pollutant is any substance that makes the water unclean or otherwise unsuitable for a particular purpose when it reaches an aquifer. Sometimes, the substance is a manufactured chemical, but it might be mi- 
crobial contamination just as often. Contamination also can occur naturally from occurring mineral and metallic deposits in rock and soil [1].

Hydrocarbon pollution and contaminants constitute serious problems wherever exploration and exploitation activities are carried out [2]. Sources of contaminants include field brines and oil spillage. Reference [3] reported over ten oil producing communities in the Niger Delta region that have experienced major oil spills and its negative environmental consequences such as fire, destruction of aquatic lives, water pollution, soil pollution and devastation of the ecosystem. According to a report by the Directorate of Petroleum Resources [4], over 6000 spills had been recorded in the 40 years of oil exploitation in Nigeria, with an average of 150 per year. In the period 1976-1996, 647 incidents occurred resulting in the spillage of 2369407.04 barrels of crude oil. With only 549060.38 barrels recovered. 1820410.50 barrels were lost to the ecosystem. Other human activities such as felling of trees, indiscriminate disposal of chemicals and refuse, flooding caused by the blockage of water ways, etc. have equally led to the devastation of the ecosystem in the study area.

Geophysical methods have been shown to be useful to the study of contaminated zones. These methods are based on the contrasts in several physical properties that typically make up the different constituents of the affected zone. In general, hydrocarbons have much lower electrical conductivity than water. This fact makes the resistivity method especially suitable for hydrocarbon contamination delineation [5] [6]. Hence, 2-D Electrical Resistivity Tomography (ERT) which provides a relatively low cost, noninvasive and rapid means of generating spatial models of physical properties of the subsurface is employed in this study.

Electrical Resistivity Tomography has been successfully applied by several researchers in the detection of pollution [7] [8].

A serious environmental concern is the movement of pollutants to the water table and subsequent contamination of drinking water resources.

The behavior of the electrical resistivity of contaminants, with respect to the host environment, depends on several factors, such as the host lithology, the moisture and the solubility of the contaminants in the groundwater. They make the 2-D ERT effective in delineating the contaminated zones due to resistivity contrasts. Fresh organic compounds in the water saturated soils usually have high electrical resistivity values.

\subsection{Background of the Study Area.}

Sapele, located in Delta State (Figure 1), Western Niger Delta, Nigeria, lies between longitude $5^{\circ} \mathrm{E}-5^{\circ} 45^{\prime} \mathrm{E}$ and latitude $5^{\circ} 30^{\prime} \mathrm{N}-6^{\circ} \mathrm{N}$ in geographic coordinate. The city hosts a flow station and an oil rig owned by one of the oil and gas companies. Figure 1 shows the map of Delta State while Figure 2 shows the picture of a fared gas taken during the survey.

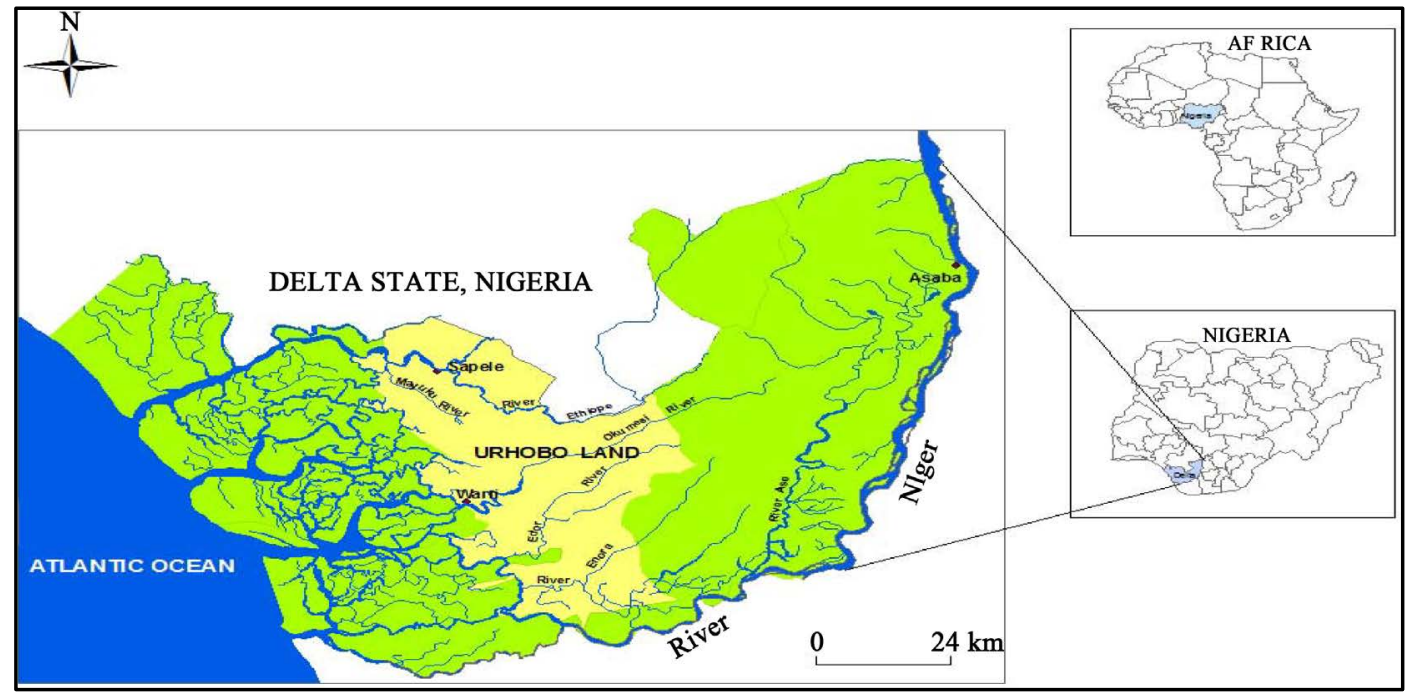

Figure 1. Map of Delta state, showing Urhboland and major Rivers of Western Niger Delta: (map drawn by Prof. Francis Odermerho, Southern Illinois University, Edwardsville; USA. Copyright: Urhobo Historical Society, 2008). 


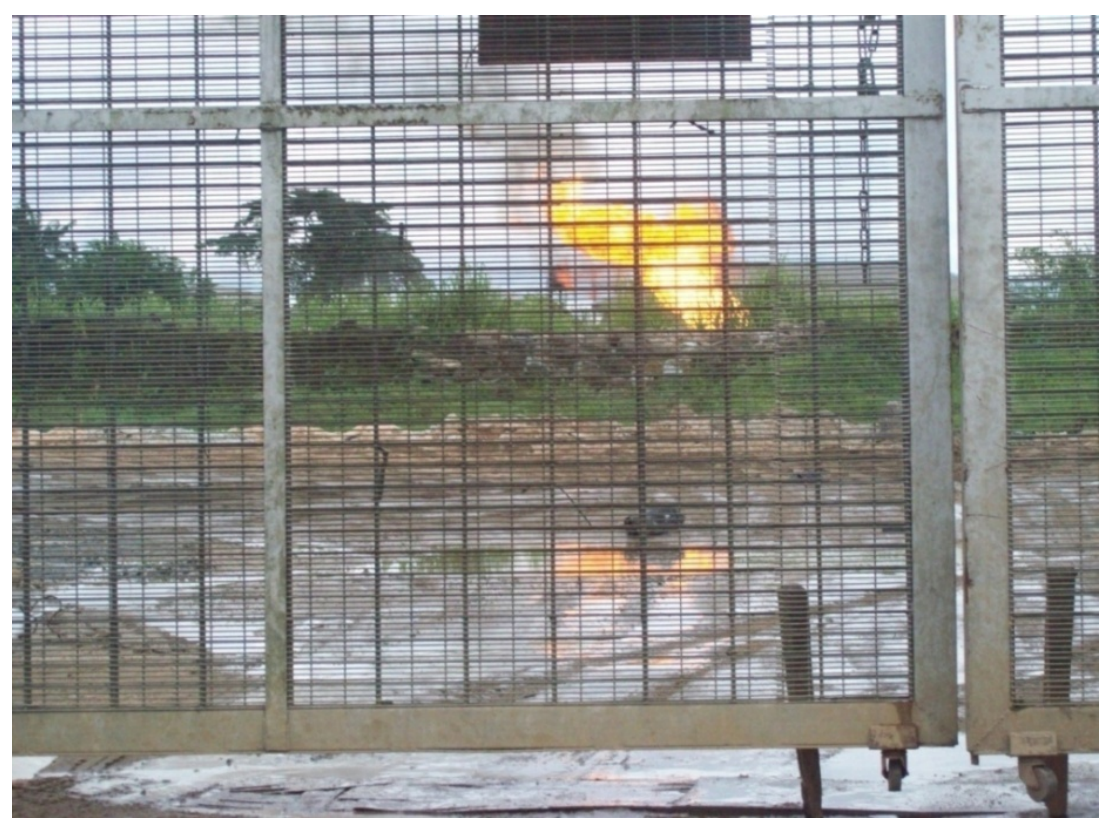

Figure 2. View of gas being flared at a flow station near the survey site in Sapele (Field Survey, October 2012).

Oil and gas production is usually accompanied by substantial discharge of wastewater in the form of brines. Constituents of brines include sodium, calcium, ammonia, boron, trace metals, and high total dissolved solids (TDS). Oil spillage is a result of leakages of hydrocarbon from the pipes, and to an extent, poor maintenance of oil pipelines and poor monitoring of pressure regimes of the fluids with respect to the strength of the pipe, equipment failure, operators error, corrosion, pigging operations, flow line replacement, flow station upgrade and the activities of vandals in search of crude and refined petroleum products [9].

As a consequent of the environmental problems highlighted above, 2-dimensional electrical resistivity imaging was carried out in a residential area close to the flow station to see if contaminants have actually infiltrated into the groundwater resources in the study area.

\subsection{Site Geology and Hydrogeology}

The Niger Delta is a large curve shaped delta which is located in Southern Nigeria like some other deltaic environments in the world. It occupies an area lying between longitude $4^{\circ} \mathrm{E}-9^{\circ} \mathrm{E}$ and latitude $4^{\circ} \mathrm{N}-6^{\circ} \mathrm{N}$. It is bounded in the west by the Calabar flank, in the north by the Anambra platform and in the south by the Atlantic Ocean under which it extends Figure 1 and Figure 3. Both marine and mixed continental depositional environment characterize the Niger Delta of Nigeria [10]. The Niger Delta covers an area of about 75,000 $\mathrm{km}^{2}(28,957$ $\mathrm{mi}^{2}$ ) in southern Nigeria, where the Niger Delta discharges its water into the Atlantic Ocean through a series of distributaries.

From the Eocene to the present, the Delta has prograded Southwest ward, forming depobelts that represent the most active portion of the Delta at each stage of its development [11]. These depobelts form one of the largest regressive deltas in the world with an area of some $300,000 \mathrm{~km}^{2}$ [12] a sediment volume of $500,000 \mathrm{~km}^{3}$ [13] and a sediment thickness of over $10 \mathrm{~km}$ in the basin depocenter.

The Niger Delta consists of three main tertiary stratigraphic units overlain by Quaternary deposit [14] shown in Table 1. These three subsurface stratigraphic units in the Niger Delta are Benin, Agbada and Akata formations. The base is the Akata formation comprising mainly of marine shale and sand beds consisting of dark grey sandy, silty shale with plant remains at the top. It is over $4000 \mathrm{ft}$ thick. The underlying Agbada formation is a sequence of sandstones and shales [15]. It consists of an upper predominantly sandy unit with minor shale intercalations and a lower shale unit which is thicker than the upper sandy unit. It is over 10,000 ft thick. The aquifer in the Benin formation is largely phreatic. These formations are overlain by various types of Quaternary deposits [15]. These areas are made up of top soil, red laterite, clay, fine sand, medium sand and coarse sand in form of 


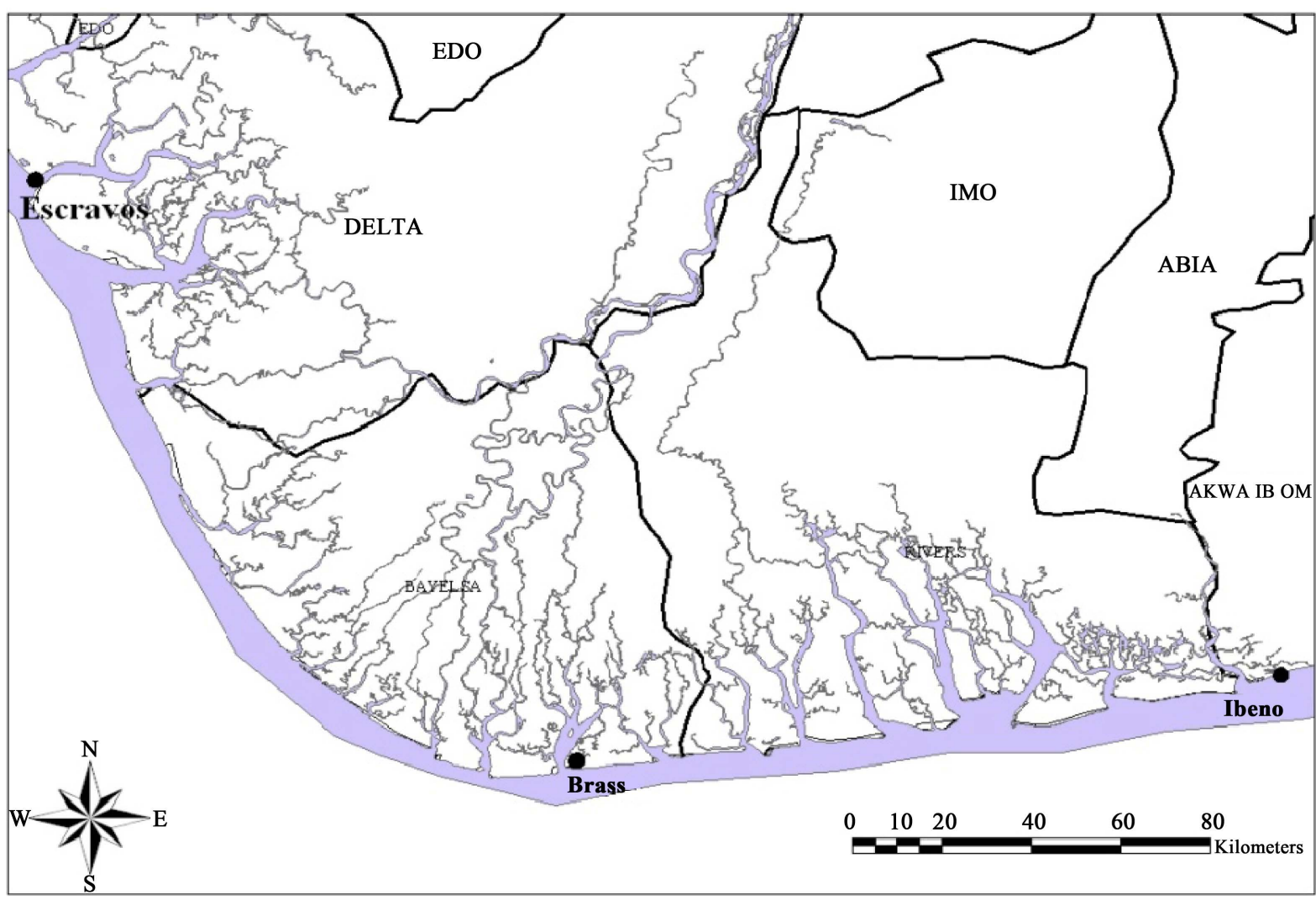

Figure 3. The Niger Delta coastline of West Africa (Short and Stauble, 1967).

Table 1. Geologic units of the Niger Delta (Short and Stauble, 1967).

\begin{tabular}{ccc}
\hline Geologic Unit & Lithology & Age \\
\hline Alluvium (general) & Gravel, sand, clay, silt & Quaternary \\
Freshwater backswamp and meander belt & Sand, clay, some silt and gravel & \\
Mangrove and salt water/backswamps & Medium-fine sand, clay and some silt & Miocene \\
Sombreiro-warri deltaic plain & Sand, clay and some silt & Eocene \\
Benin formation (coastal plain sand) & Coarse to medium sand with subordinate silt and clay lenses & Paleocene \\
Agbada formation & Mixture of sand, clay and silt & Clay \\
Akata formation & &
\end{tabular}

pebbles. The thickness is variable but generally exceeds $6000 \mathrm{ft}$ [16].

The deposits of the Freshwater Swamps and the Sombreiro-Warri Deltaic Plain are universally considered to be recent expressions of and a continuation of the Benin Formation. They result from the sediment laden discharges of the River Niger that is spread on the delta by its various tributaries. The sediment is generally an admixture of medium to coarse-grained sands, sandy clays, silts and clays that eventually settle in fluvial/tidal channel, tidal flat and mangrove swamp environments, a process that has been ongoing since the late Quaternary and is related to interglacial marine transgressions [17]-[19]. The Niger Delta is one of the most hydrocarbon-rich regions in the world. Exploration and exploitation of hydrocarbons has been going on in the region since 1956, when oil was discovered there [20]. The oil and gas production and a rapidly growing population have resulted in environmental degradation of the Delta [21].

The study area consists of Fresh water swamp, Coastal Plain Sands, Mangrove swamps, and Sombreiro-Warri plains [22]. The water table in the study area is approximately 4 to $5 \mathrm{~m}$ beneath the surface, and the direction of 
flow is towards River Ethiope which drains into the Atlantic ocean through the Benin River (Figure 1).

\subsection{Electrical Resistivity and Hydrocarbon Pollution}

2-dimensional model, where the resistivity changes in the vertical direction, as well as in the horizontal direction along the survey line was employed in the study area to image the subsurface. In this case, it is assumed that resistivity does not change in the direction that is perpendicular to the survey line.

Geophysical methods are frequently used to study subsoil contamination caused by industrial residues of different nature. The effectiveness of electrical methods for the characterization of oil contaminated subsoil has been reported by several researchers [23]-[26].

Geoelectric method (Resistivity method) has been used by several researchers to study environmental problems and groundwater studies. Reference [27] used Geoelectric method in the evaluation of Olushosun landfill site Southwest Nigeria and its implication on Groundwater. Geophysical and hydrochemical assessment of groundwater pollution due to a dumpsite in Lagos State was also conducted by [28].

References [9] [29] also found out that high hydrocarbon content of soils has been known to affect soil physiochemical properties, which in turn affect the agricultural potentials of such soils. Hence, this work attempts to find out if hydrocarbon has infiltrated into the groundwater in the study area.

Hydrocarbon pollution is very complex. Fresh spilled hydrocarbon gives different result from aged spills. The following results from some researchers give clue on what to expect from the investigation in the study area.

Reference [30] in their work on "Two-dimensional electrical imaging for detection of hydrocarbon contaminants" pointed out the usefulness and the pitfalls of electrical tomography in the characterization of underground leakage of hydrocarbons. Experimental evidence, obtained from a joint geochemical and geophysical investigation approach, indicated that subsoil which has been saturated with diesel oil for a long period ( $>20$ years) exhibits an increased conductivity. It suggests that electrical tomography could be useful for monitoring the effects of induced biodegradation (bioremediation) through the repetition of the survey at different times, in order to observe any changes in the resistivity due to the increase of free ions resulting from hydrocarbon degradation.

Electrical resistivity models for oil contamination in some area showed high resistivity [31] and low resistivity [32] [33]. Recent oil pollution shows a high resistivity anomaly, while mature oil pollution produces a low resistivity anomaly [32]. Months after spill, a low resistivity anomaly is developed in the contaminated zone, with a strength that depends on the geological characteristics of the subsoil [32] [34]. The formation processes of such low resistivity anomaly are related to chemical reactions and to variations in the physical characteristics of the oil contaminated zone. The low resistivity anomaly is caused by an increase in the total dissolved solids (TDS), due to bacterial degradation of hydrocarbons in the lower part of the vadose zone. Reference [32] found that aged contamination appears as a low resistivity horizon slightly above groundwater table (GWT).

\section{Materials and Method}

64 multi-electrode Terrameter was used for the electrical imaging with $2 \mathrm{~m}$ minimum electrode spacing. Each traverse covered a lateral distance of $126 \mathrm{~m}$. Three traverses were taken proximal to the oil rig, flow station and oil pipelines (Figure 4). We could not get too close to the pipelines and other installations due to restrictions by the oil companies and the presence of security forces monitoring the installations. The areas we took the traverses were the only allowed areas.

Environmental geophysical surveys are concerned with near surface, typically to depths of less than $30 \mathrm{~m}$. So a small electrode spacing of $2 \mathrm{~m}$ was adopted, in order to be able to provide considerable details of any plumes related to leakages from the underground pipes and flow stations. It is well known that the Wenner array is relatively sensitive to vertical changes of resistivity below the centre of the array, and Gradient array exploit the advantages of Schlumberger and Wenner arrays. So, Wenner array and Gradient methods were chosen in the acquisition of data because of good vertical resolution, less sensitivity to noise and better lateral coverage.

Computer iteration was carried out on the data obtained, using the Earth Imager software. This software simulates the values of the apparent resistivity and that of the current electrode spacing to obtain a two dimensional (2D) layered model. Consequently, resistivities and the depths of the layers were estimated. Borehole logs (Figure 5 and Figure 6) of the study area collected from The Federal Ministry of Water Resources, Asaba were used as an aid in the interpretation of the electrical resistivity tomography results. The elevation of the study area is about $3-4 \mathrm{~m}$. 


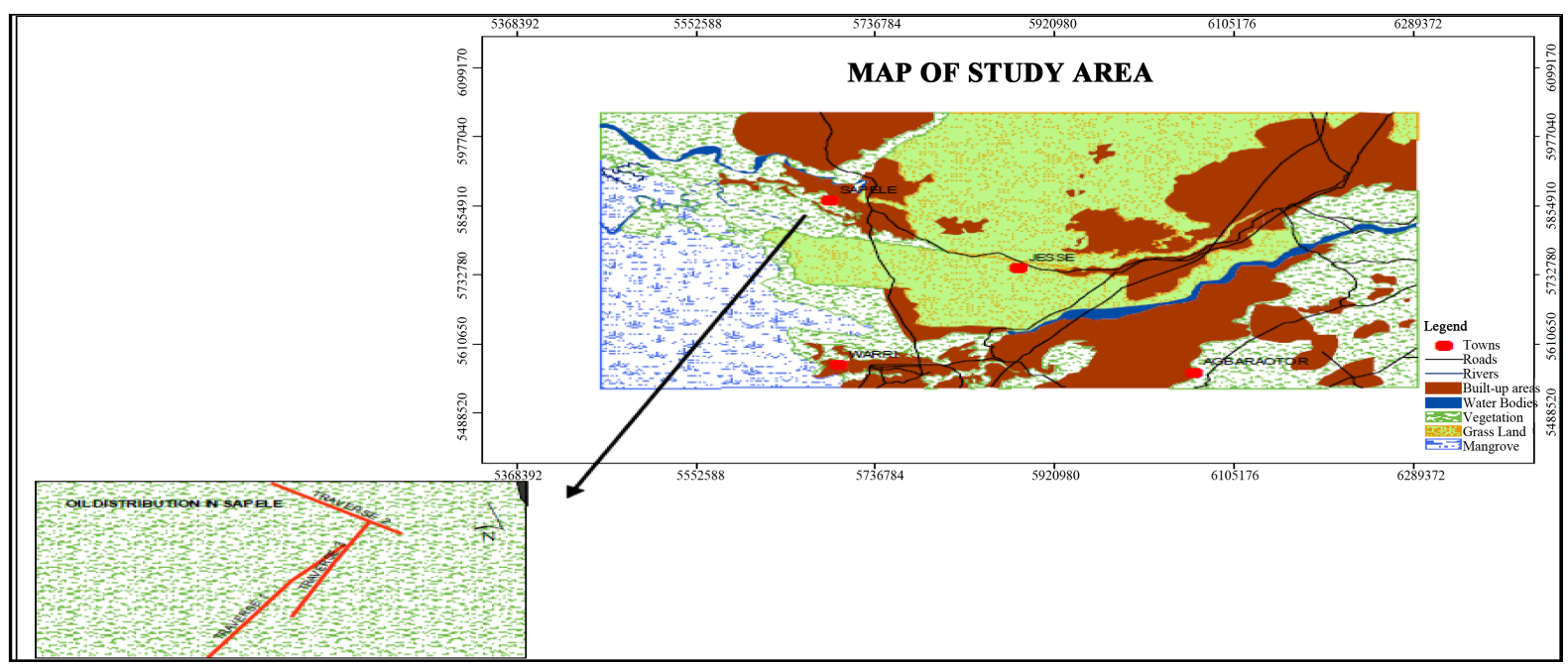

Figure 4. Map of Sapele showing the traverse lines.

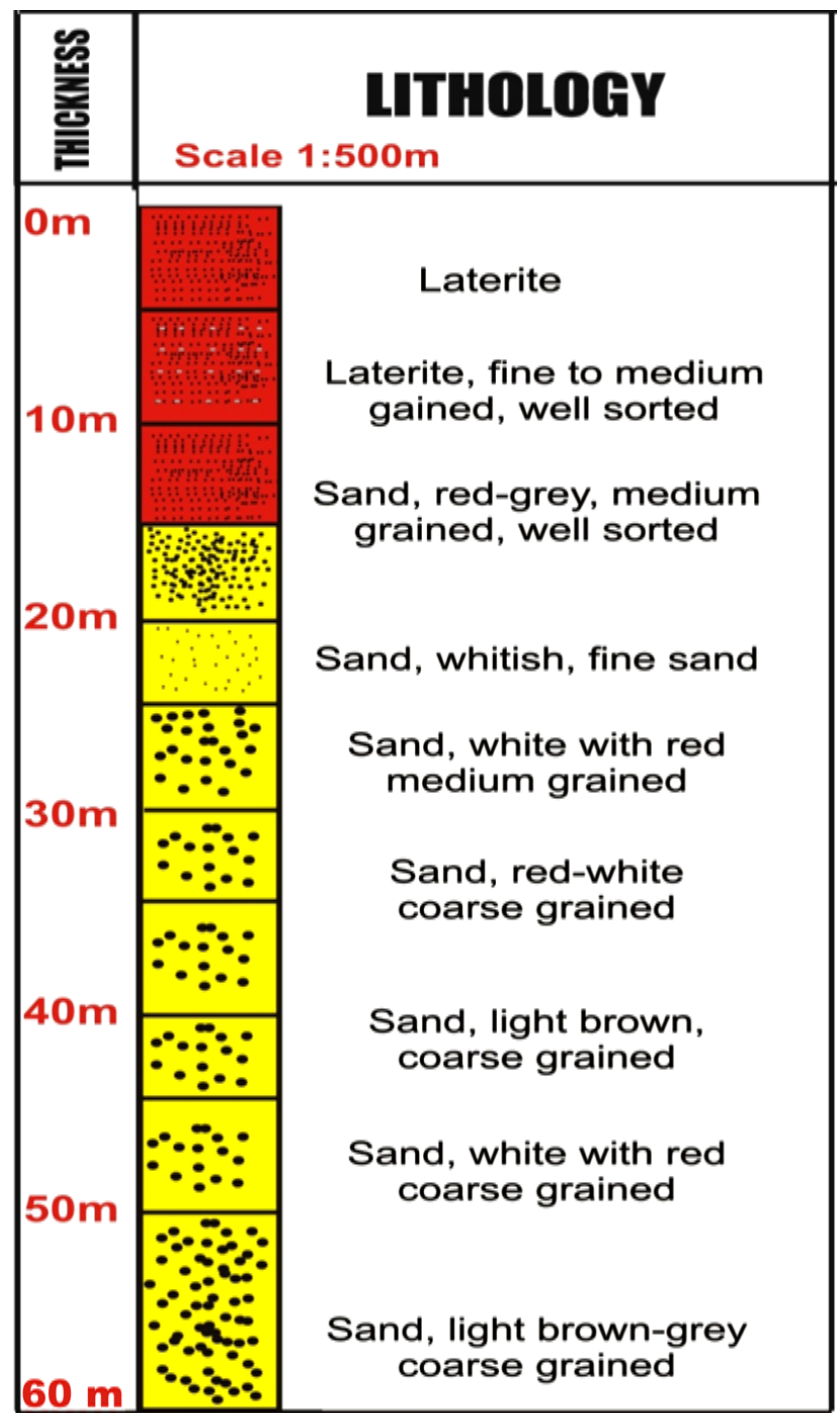

Figure 5. Borehole 1: lithologic description of the study area (Courtesy: Federal Ministry of Water Resources, Asaba). 


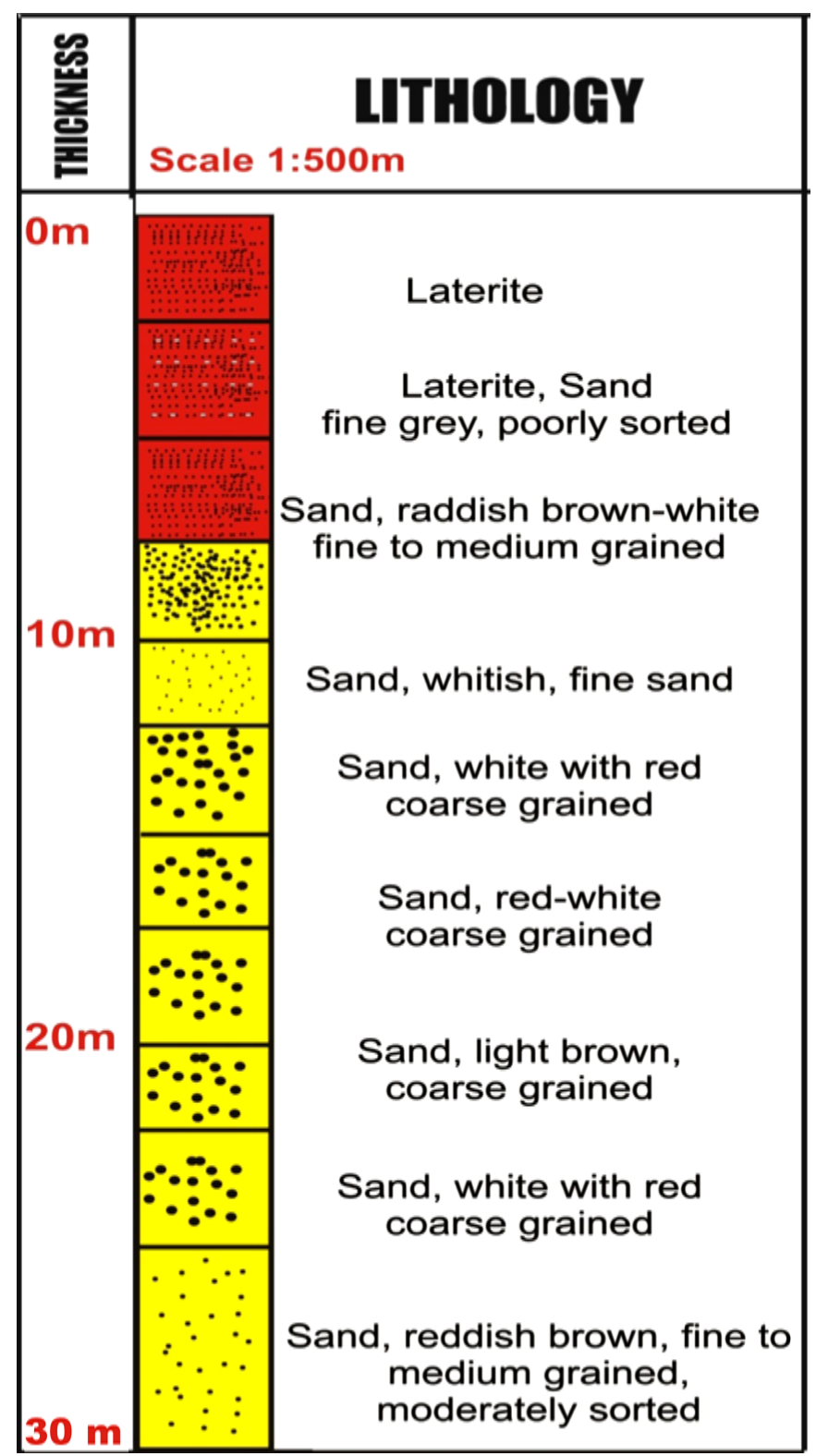

Figure 6. Borehole 2: lithologic description of the study area (Courtesy: Federal Ministry of Water Resources, Asaba).

\section{Results and Discussion}

The results and discussion of the Electrical Resistivity Tomography of the study area is given below.

\subsection{Traverse 1}

Traverse 1 reveals the resistivity image along the profile. Figure 7(a) and Figure 7(b) show the Gradient and Wenner array maps respectively.

Integration of the two 2-D ERT array results show that subsurface is characterized with soil material with resistivity ranging from 42 - 15,000 $\Omega \cdot \mathrm{m}$ reflective of varying degree of conductivity associated with varying lithology and fluid type. Figure 5 and Figure 6 are the borehole data used for comparing the interpretation of the 2-D ERT section.

The ERT result shows that the subsurface is composed predominantly of sand material from the surface to a depth of about $60 \mathrm{~m}$ beneath the surface. The 2-D electrical resistivity imaging result (Figure 7(A)) show the 


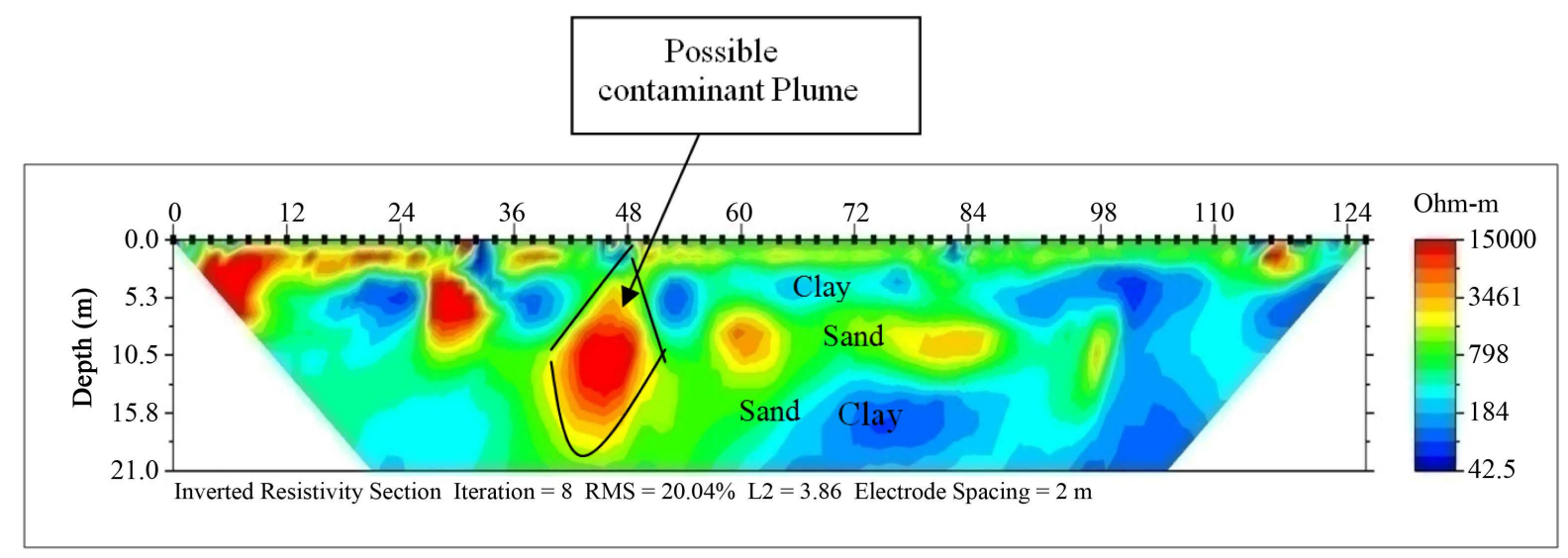

(a)

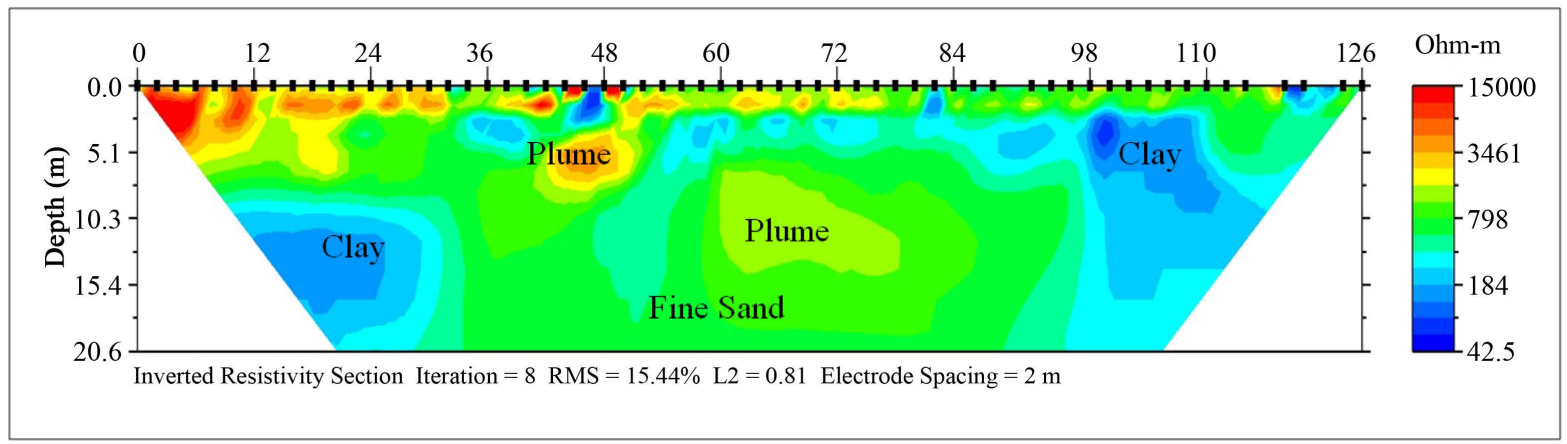

(b)

Figure 7. (a) Sapele (traverse 1) Gradient array; (b) Sapele (traverse 1) Wenner array.

resistivity distribution over a lateral distance of $126 \mathrm{~m}$ from the surface to a depth of about $21 \mathrm{~m}$ beneath the surface. The 2-D section revealed an anomalously high resistivity $(1500-15,000 \Omega \cdot \mathrm{m})$ structure within a lateral distance of 2 - $32 \mathrm{~m}$; 36 - $40 \mathrm{~m}$; 40 - $52 \mathrm{~m}$; 58 - $63 \mathrm{~m}$; 76 - $86 \mathrm{~m}$; and 114 - $118 \mathrm{~m}$ at a depth of 0.5 - $9 \mathrm{~m}$; 0.1 - 1 m; 5 - $18 \mathrm{~m} ; 7$ - $11 \mathrm{~m} ; 8$ - $10 \mathrm{~m}$; and 0 - $2 \mathrm{~m}$ respectively. These anomalously high resistivity structures are attributed to the presence of hydrocarbon within the subsurface which may be due to leakages from various pipelines within the study area or possible activity of the vandals.

Correlation with the borehole data (Figure 5 and Figure 6) shows that the subsurface is characterized predominantly with sand, and may compose of clayey sand/clay in some locations. The 2-D ERT result shows that the resistivity within the depth of investigation ranges from $45-15,000 \mathrm{Ohm}-\mathrm{m}$. Since the formation in the study area is compose of sand with water table between 4 - $5 \mathrm{~m}$ beneath the surface, the high resistivity $(\geq 1500 \Omega \cdot \mathrm{m})$ is a possible indication that the aquifer within this area may have been polluted by hydrocarbon.

\subsection{Traverse 2}

Figure 8(a) and Figure 8(b) show the Gradient and Wenner array 2D resistivity structures. The two resistivity structures also show that the subsurface is equally compose of varying degrees of resistivity as can be seen from the resistivity values $(43-15,000 \Omega \cdot \mathrm{m})$, revealing varying degree of conductivity associated with lithology and fluid type.

The 2-D section also revealed an anomalously high resistivity (2000 - 15,000 $\Omega \cdot \mathrm{m})$ structure within a varying lateral and vertical location distributed over the entire traverse. At a lateral distance of 2 - $58 \mathrm{~m}$, possible hydrocarbon pollution were noticed at a depth of $0.5-6 \mathrm{~m}$, while at a lateral distance of $60-126 \mathrm{~m}$ the depth of pollution vary from 0.5 - $21 \mathrm{~m}$ beneath the surface.

Integration of the two array maps and correlation with the borehole data (Figure 5 and Figure 6) show that the resistivity of the sand layer within the depth of investigation of the 2-D ERT ranges from $45-15,000 \Omega \cdot \mathrm{m}$ and may compose of fine to coarse sand/clay in some location. 


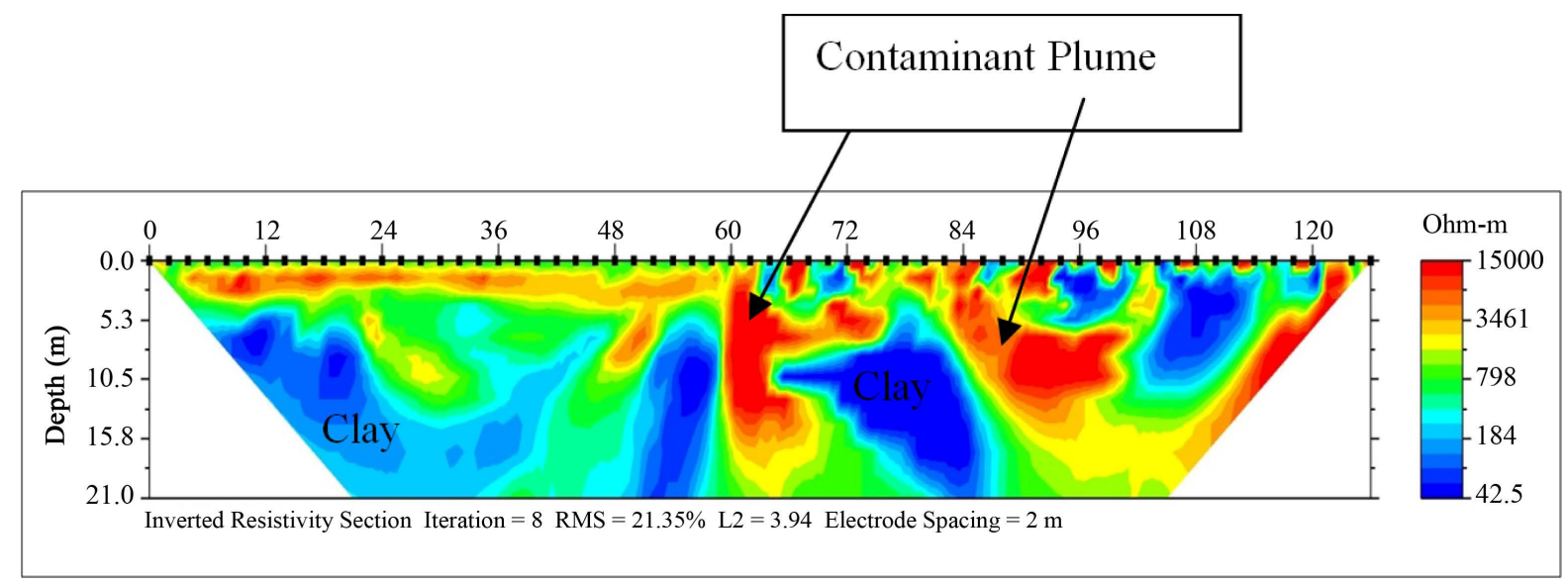

(a)

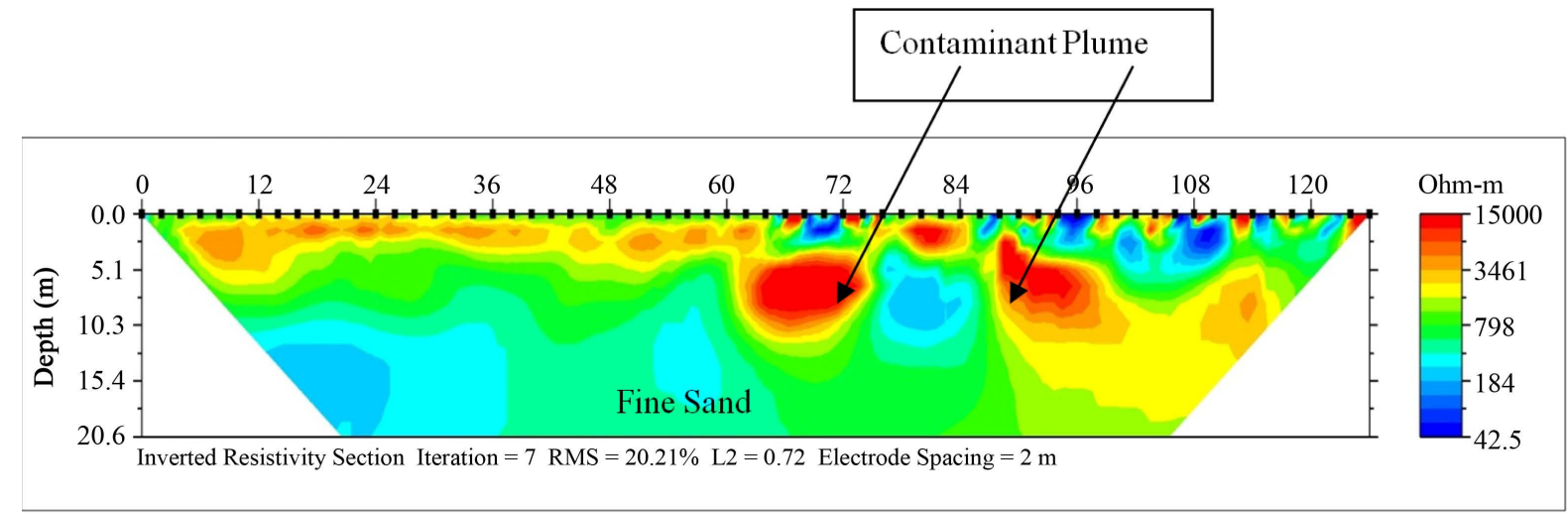

(b)

Figure 8. (a) Sapele (traverse 2) Gradient array; (b) Sapele (traverse 2) Wenner array.

\subsection{Traverse 3}

Traverse three reveal the resistivity image along the survey line. Figure 9(a) and Figure 9(b) show the Gradient and Wenner array structures respectively.

Integration of the 2-D ERT array results show that the subsurface has soil materials with resistivity ranging from $42.5-15,000 \Omega \cdot \mathrm{m}$ indicative of changing degree of resistivity associated with varying lithology and fluid type. The 2-D section revealed an anomalously high resistivity $(1500-15,000 \Omega \cdot \mathrm{m})$ structure within a lateral distance 2 - $16 \mathrm{~m}$ within a depth of 0.1 - $6 \mathrm{~m}$ reflective of near surface hydrocarbon pollution. Similar occurrence was noticed within a lateral distance of $62-126$ at a depth of 0.1 to $4 \mathrm{~m}$; however within a lateral distance of $20-70 \mathrm{~m}$ and within $86-100 \mathrm{~m}$ the hydrocarbon pollution seems to have migrated to a depth of about $21 \mathrm{~m}$ beneath the surface. This may be a clear evidence of groundwater pollution by the hydrocarbon since the water table lies within 4 - $5 \mathrm{~m}$ within the study area.

\section{Conclusion}

The 2-D Electrical Resistivity Tomography results of the study area show that the subsurface is characterized with soil material with resistivity ranging from $42-15,000 \Omega \cdot \mathrm{m}$, reflective of varying degree of conductivity associated with changing lithology and fluid type. Correlation with borehole data shows that the subsurface is predominantly composed of sand material from the surface to a depth of about $60 \mathrm{~m}$ beneath the surface, with anomalously high resistivity $\geq 1500 \Omega \cdot \mathrm{m}$ in most parts. This low conductivity formations can be attributed to hydrocarbon which is an indication that shallow aquifer in the study area has been polluted. It is recommended that water from hand dug well should not be used for drinking and certain domestic work. Moreover, geophysical investigation should be carried out in the study area before sinking boreholes. 


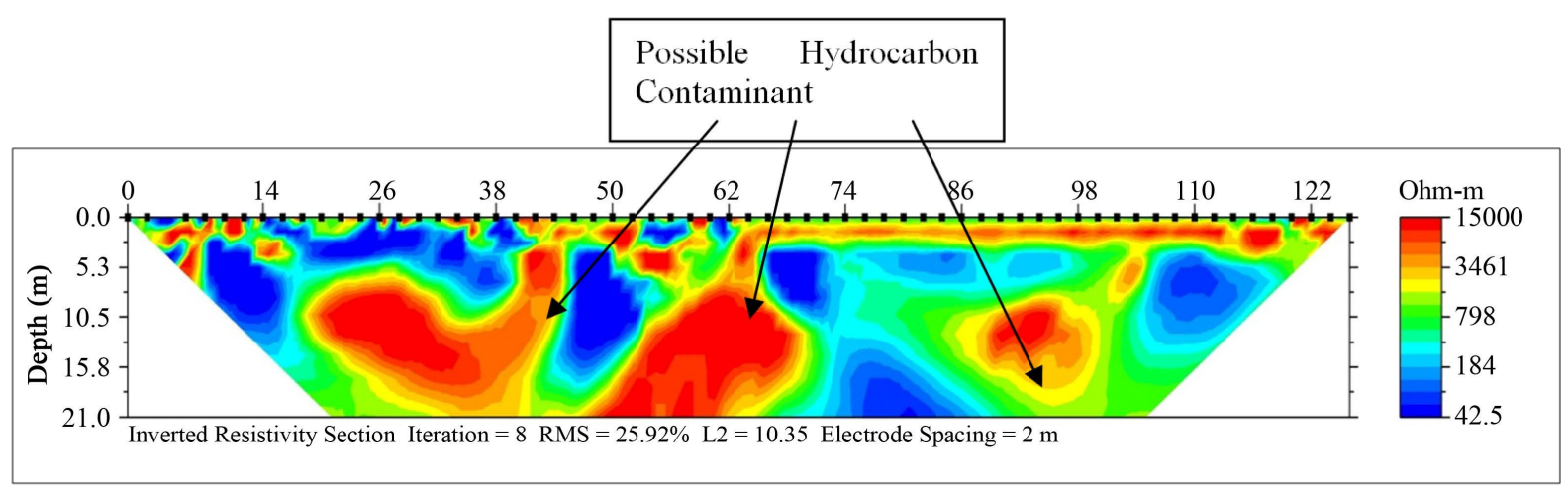

(a)

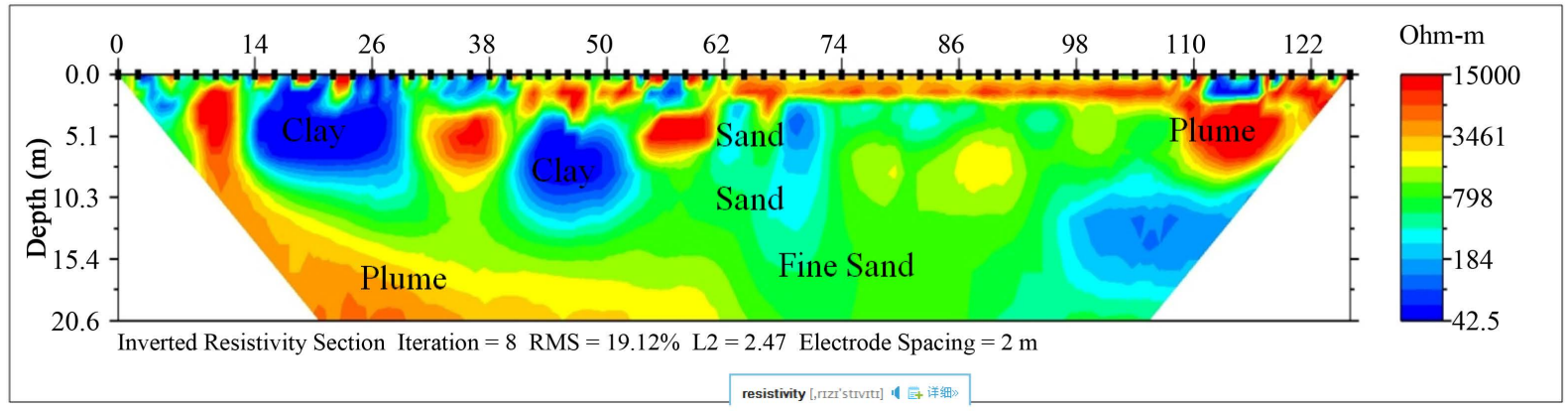

(b)

Figure 9. (a) Sapele (traverse 3) Gradient array; (b) Sapele (traverse 2) Wenner array.

\section{Acknowledgements}

We thank the Federal Ministry of Water Resources, Asaba for providing us the borehole data of the study area.

\section{References}

[1] Boulding, J.R. (1995) Practical Handbook of Soil, Vadose Zone, and Ground-water Contamination: Assessment, Prevention, and Remediation. Lewis Publishers, Boca Raton.

[2] Atakpo, E.A. and Ayolabi, E.A. (2008) Evaluation of Aquifer Vulnerability and the Protective Capacity in Some Oil Producing Communities of Western Niger Delta, Nigeria. The Environmentalist. http://dx.doi.org/10.1007/s10669-008-9191-3

[3] Ekoriko, M. and Egwu, E. (1995) Neglect of Oil Communities Rage of the People. Newswatch Magazine, 18 December 1995, 13.

[4] DPR (1997) Department of Petroleum Resources. Annual Reports, Abuja, 191 p.

[5] Fetter, C.W. (1993) Contaminant Hydrogeology. Prentice-Hall, Inc., Upper Saddle River.

[6] Reynolds, J. (1998) An Introduction to Applied and Environmental Geophysics. John Wiley \& Sons Ed., New York.

[7] Daily, W., Ramirez, A. and Johnson, R. (1998) Electrical Impedance Tomography of a Perchloroethelyne Release. Journal of Environmental and Engineering Geophysics, 2, 189-201.

[8] Goes, B.J.M. and Meekes, J.A.C. (2004) An Effective Electrode Configuration for the Detection of DNAPLs with Electrical Resistivity Tomography. Journal of Environmental and Engineering Geophysics, 9, 127-141. http://dx.doi.org/10.4133/JEEG9.3.127

[9] Ezebuiro, P.E. (2004) A Review of Effect of Oil Pollution in West African Environment. Science and Nature, 5, 14-18.

[10] Uko, E.D., Ekine, A.S., Ebeniro, J.O. and Ofoegbu, C.O. (1992) Weathering Structure of the East-Central Niger Delta, Nigeria. Geophysics, 57, 1228-1233. http://dx.doi.org/10.1190/1.1443338

[11] Doust, H. and Omatsola, E. (1990) Niger-Delta. In: Edwards, J.D. and Santogrossi, P.A., Eds., Divergent/Passive Margin Basins, AAPG Memoir 48, American Association of Petroleum Geologists, Tulsa, 239-248.

[12] Kulke, H. (1995) Nigeria. In: Kulke, H., Ed., Regional Petroleum Geology of the World, Part II, Africa, America, Aus- 
tralia and Antarctica, Gebruder Borntraeger, Berlin, 143-172.

[13] Hospers, J. (1965) Gravity Field and Structure of the Niger-Delta, Nigeria, West Africa. Geological Society of America Bulletin, 76, 407-422. http://dx.doi.org/10.1130/0016-7606(1965)76[407:GFASOT]2.0.CO;2

[14] Short, K.C. and Stauble, A.J. (1967) Outline of the Geology of Niger Delta. American Association of Petroleum Geologists Bulletin, 51, 761-779.

[15] Merki, P.J. (1970) Structural Geology of the Cenozoic Niger Delta. African Geology, University of Ibadan Press, Ibadan, 251-268.

[16] Egbai, J.C. (2011) Resistivity Method: A Tool for Identification of Areas of Corrosive Groundwater in Agbor, Delta State, Nigeria. Journal of Emerging Trends in Engineering and Applied Sciences (JETEAS), 2, 226-230.

[17] Allen, J.R.L. (1965) Late Quaternary Niger Delta and Adjacent Areas: Sedimentary Environments and Lithofacies. American Association of Petroleum Geologists Bulletin, 49, 547-600.

[18] Oomkens, E. (1974) Lithofacies Relations in the Late Quaternary Niger Delta Complex. Sedimentology, 21, $195-222$. http://dx.doi.org/10.1111/j.1365-3091.1974.tb02056.x

[19] Durotoye, B. (1975) Quaternary Sediments in Nigeria. In: Kogbe, C.A., Ed., Geology of Nigeria, Rockview, Jos, 431-444.

[20] Oloibiri (2014) The Community that Hosted Nigeria’s First Oil Well in 1956. http://www.premiumtimesng.com

[21] Obasi, R.A. and Balogun, O. (2001) Water Quality and Environmental Impact Assessment of Water Resources in Nigeria. African Journal of Environment Studies, 2, 228-231.

[22] Omo-Irabor, O.O. and Oduyemi, K. (2006) A Hybrid Image Classification Approach for the Systematic Analysis of Land Cover (LC) Changes in the Niger Delta Region. Proceedings of the 6th Int'l Conference on Earth Observation and Geoinformation Sciences in Support of Africa's Development, Cairo, 30 October-2 November 2006.

[23] Vanhala, H., Soininen, H. and Kukkonen, I. (1992) Detecting Organic Chemical Contaminants by Spectral Induced Polarization Method in Glacial Till Environment. Geophysics, 57, 1014-1017. http://dx.doi.org/10.1190/1.1443312

[24] Atekwana, E.A., Sauck, W.A. and Werkemer, D.D. (2000) Investigations of Geophysical Signatures at a Hydrocarbon Contaminated Sites. Journal of Applied Geophysics, 44, 167-180. http://dx.doi.org/10.1016/S0926-9851(98)00033-0

[25] Atekwana, E.A., Sauck, W.A., Abdel Aal, G.Z. and Werkema Jr., D.D. (2002) Geophysical Investigation of Vadose Zone Conductivity Anomalies at a Hydrocarbon Contaminated Site: Implications for the Assessment of Intrinsic Bioremediation. Journal of Environmental \& Engineering Geophysics, 7, 103-110. http://dx.doi.org/10.4133/JEEG7.3.103

[26] Osella, A., de la Vega, M. and Lascano, E. (2002) Characterization of a Contaminant Plume Due to a Hydrocarbon Spill Using Geoelectrical Methods. Journal of Environmental \& Engineering Geophysics, 7, 78-87.

[27] Ayolabi, E.A. (2005) Geoelectric Evaluation of Olushosun Landfill Site Southwest Nigeria and Its Implication on Groundwater. Journal of Geological Society of India, 66, 318-322.

[28] Ayolabi, E.A. and Folashade, J.O. (2005) Geophysical and Hydrochemical Assessment of Groundwater Pollution Due to Dumpsite in Lagos State, Nigeria. Journal of Geological Society of India, 66, 617-622.

[29] Amadi, A., Dickson, A. and Maate, G.O. (1993) Effect of Organic and Inorganic Nutrient Supplements on the Performance of Maize (Zea may L). Water, Air, and Soil Pollution, 66, 59-76.

[30] Godio, A. and Naldi, M. (2003) Two-Dimensional Electrical Imaging for Detection of Hydrocarbon Contaminants. Near Surface Geophysics, 2003, 131-137.

[31] Osella, A., de la Vega, M. and Lascano, E. (2002) Characterization of a Contaminant Plume Due to a Hydrocarbon Spill Using Geoelectrical Methods. Journal of Environmental \& Engineering Geophysics, 7, 78-87. http://dx.doi.org/10.4133/JEEG7.2.78

[32] Sauck, W.A. (2000) A Model for the Resistivity Structure of LNAPL Plumes and Their Environs in Sandy Sediments. Journal of Applied Geophysics, 44, 151-165. http://dx.doi.org/10.1016/S0926-9851(99)00021-X

[33] Cassidy, D.P., Werkema, D.D., Sauck, W.A., Atekwana, E.A., Rossbach, S. and Duris, J. (2001) The Effects of LNAPL Biodegradation Products on Electrical Conductivity Measurements. Journal of Environmental \& Engineering Geophysics, 6, 47-52. http://dx.doi.org/10.4133/JEEG6.1.47

[34] Omar, D.R., Vladimir, S., Jesús, O.V. and Albert, R. (2006) Using Electrical Techniques for Planning the Remediation Process in a Hydrocarbon Contaminated Site. Revista Internacional de Contaminación Ambiental, 22, 157-163. 
Scientific Research Publishing (SCIRP) is one of the largest Open Access journal publishers. It is currently publishing more than 200 open access, online, peer-reviewed journals covering a wide range of academic disciplines. SCIRP serves the worldwide academic communities and contributes to the progress and application of science with its publication.

Other selected journals from SCIRP are listed as below. Submit your manuscript to us via either submit@scirp.org or Online Submission Portal.
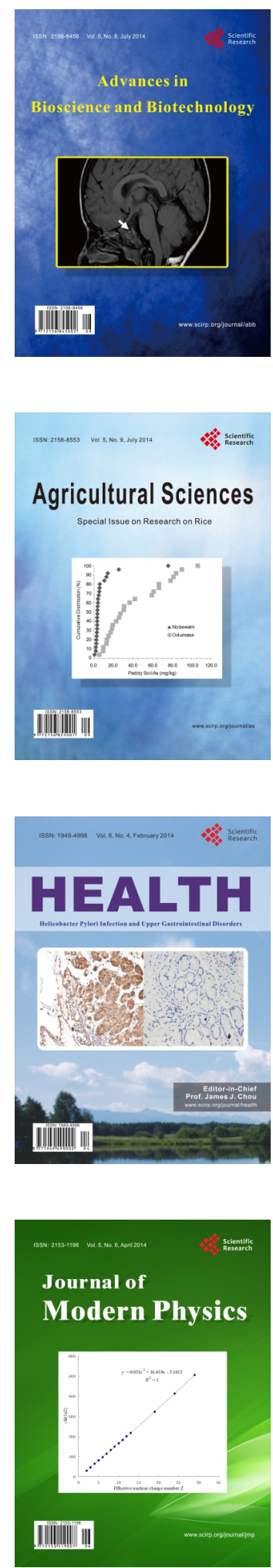
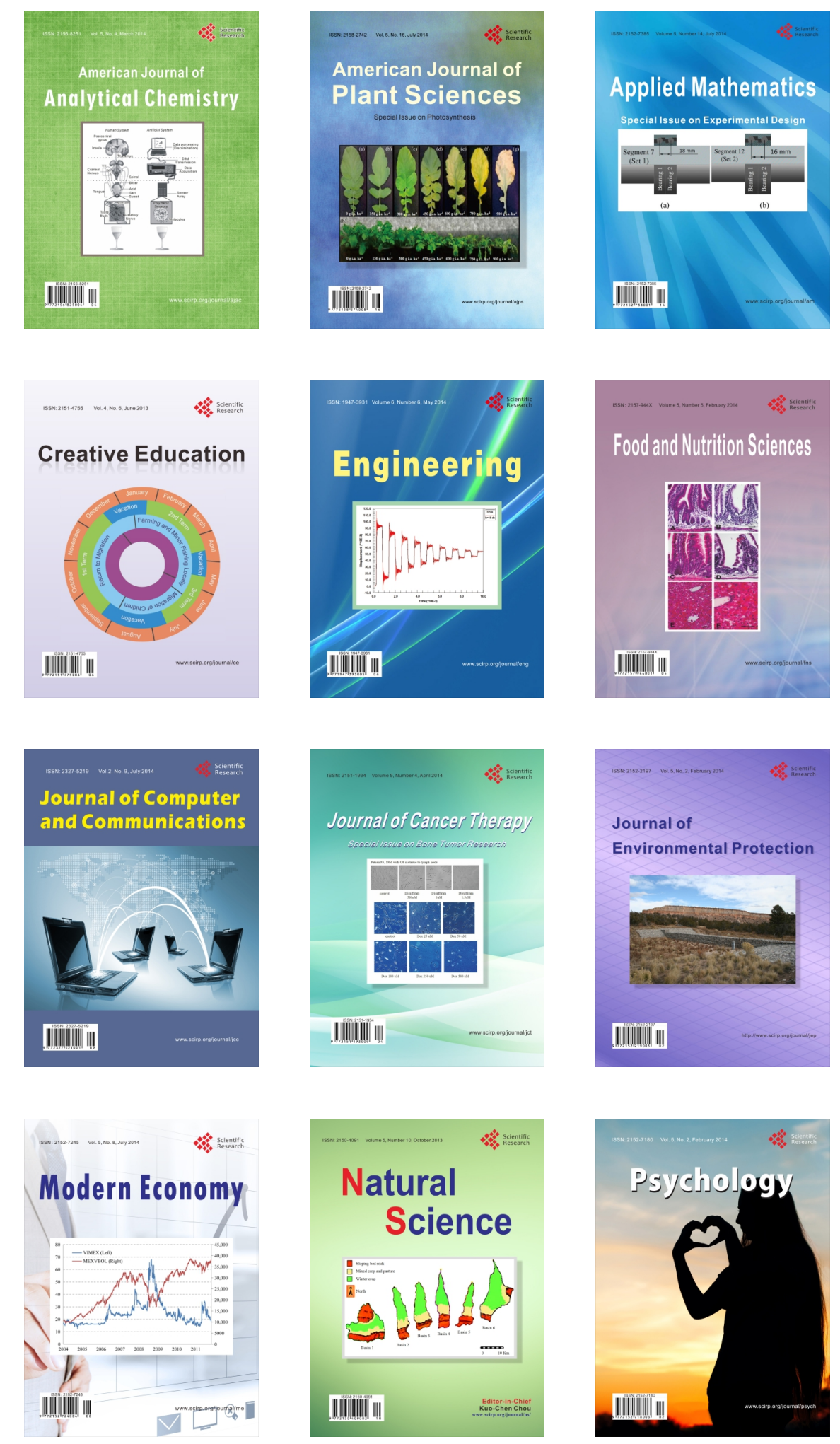